\title{
Quality of life of HIV+ patients undergoing pharmacotherapeutic follow-up
}

\author{
Catarine Vitor Loureiro', Henry Pablo Lopes Campos e Reis ${ }^{1}$, Karla do Nascimento Magalhães², \\ Cristiane Policarpo Carmo², Francisca Ana Maria Leite ${ }^{2}$, Ana Cláudia de Brito Passos ${ }^{3}$, Paulo Yuri \\ Milen Firmino ${ }^{1}$, Nadir Kheir ${ }^{1,4}$, David John Woods ${ }^{1,5}$, Ângela Maria de Souza Ponciano ${ }^{1}$, Marta \\ Maria de França Fonteles, ${ }^{1, *}$
}

${ }^{1}$ Centre of Studies in Pharmaceutical Care (CEATENF)/Research Group on Pharmaceutical Care (GRUPATF)/ CNPq, Federal University of Ceará, ${ }^{2} J o s e ́ ~ d e ~ A l e n c a r ~ M e d i c a l ~ S p e c i a l t i e s ~ C e n t e r ~(C E M J A), ~ '{ }^{3}$ Drug Information Center (CIM), Federal University of Ceará, ${ }^{4}$ Qatar University, Doha, ${ }^{5}$ School of Pharmacy, Otago University, and Best Practice Advocacy Centre, $B P A C$, New Zealand

\begin{abstract}
The influence of pharmacotherapeutic follow-up (PTF) on quality of life was evaluated in $45 \mathrm{HIV}_{+}$ patients, who were undergoing initial antiretroviral therapy at a specialized care center in northeast Brazil. PTF lasted nine months and quality of life was analyzed at the 1st and 9th meetings using a questionnaire validated for Brazil. The study identified 643 problems related to antiretrovirals and there were 590 pharmaceutical interventions during the PTF. The comparative analysis between the results of the 1st and the 9th meeting was statistically significant for all domains of the questionnaire. For asymptomatic patients, only one domain was statistically significant. For symptomatic patients, six domains were significant. Patients with one year of HIV/AIDS diagnosis had statistically significant differences in five domains. The results suggest that the PTF contributed to improving quality of life, particularly for symptomatic patients and those diagnosed for at least one year - important target groups for Pharmaceutical Treatment.
\end{abstract}

Uniterms: Pharmacotherapeutic follow-up/influence/quality of life. HIV patients/quality of life. Pharmaceutical care.

A influência do seguimento farmacoterapêutico (SFT) sobre a qualidade de vida foi avaliada em 45 pacientes $\mathrm{HIV}_{+}$assistidos em serviço de atendimento especializado do nordeste brasileiro. O SFT teve duração de 9 meses e a qualidade de vida foi analisada no $1^{\circ}$ e $9^{\circ}$ encontros através de questionário validado no País. Identificaram-se 643 problemas relacionados aos antirretrovirais e realizaram-se 590 intervenções farmacêuticas durante o SFT. A análise comparativa entre os resultados de qualidade de vida do $1^{\circ}$ e $9^{\circ}$ encontro foi estatisticamente significativa em todos os domínios do questionário. Quando analisados somente os pacientes assintomáticos, apenas um domínio apresentou significância estatística. Entre os sintomáticos, seis domínios foram significativos. Pacientes com até um ano de diagnóstico de HIV/AIDS apresentaram validade estatística em cinco domínios. Os resultados sugerem que o SFT contribuiu para a melhoria da qualidade de vida dos pacientes, sobretudo dos sintomáticos e/ou com até um ano de diagnóstico, representando grupos-alvo para a prática da Atenção Farmacêutica.

Unitermos: Seguimento farmacoterapêutico/influência/qualidade de vida. Paciente de HIV/qualidade de vida. Atenção Farmacêutica.

\footnotetext{
*Correspondence: M. M. F. Fonteles. Centro de Estudos em Atenção Farmacêutica (CEATENF), Departamento de Farmácia, Universidade Federal do Ceará. R. Cel. Francisco Pedro, n.1210, 60430-170 - Fortaleza - CE, Brasil. E-mail: martafonteles@yahoo.com.br
} 


\section{INTRODUCTION}

The first case of AIDS, a disease caused by the human immunodeficiency virus (HIV), was identified over 25 years ago; since then, there has been a significant decrease in morbidity and mortality among HIV-infected people as a result of improvement in access to care, prophylaxic treatment for opportunistic infections and antiretroviral therapy (ART) (Aberg et al.,2009).

The Brazilian STD/AIDS program has become internationally recognized for its widespread use of, and access to, antiretroviral therapy, and for the improvements it has achieved in the indicators of morbidity, mortality and quality of life. However, the profile of the disease has now become chronic-degenerative (Brasil, 2008).

Although ART has undoubtedly positive effects (it promotes a profound and constant suppression of HIV replication, restores immune function, reduces morbidity and mortality and promotes positive therapeutic outcomes for patients infected with HIV (Palella et al., 1998), there are numerous factors that can hamper the achievement of desired goals, including the pathogenicity of the virus strain, a patient's basal levels, the appearance of resistance and non-adherence to treatment (Chesney, Morin, Sherr, 2000; Bartlett, 2002). Additionally, some people that have received antiretroviral therapy for a long period, live with the effects of drug toxicity such as lipodystrophy, and coinfections - Hepatitis B or C - (Brasil, 2008).

Antiretroviral treatment has many factors that can hinder adherence: the use of more than one drug, a regimen involving more than one dose per day, the presence of adverse effects, prolonged treatment and asymptomatic patients (Chesney, Morin, Sherr, 2000; Walsh et al., 2001). These drawbacks of antiretroviral therapy directly interfere with the quality of life of HIV-infected patients.

According to the literature review by Canini et al. (2004), most studies that assess quality of life have been developed in the U.S. or developed countries; however, in recent years, scientists have recognized the need for worldwide research on this subject, including in Brazil, where epidemiological data have shown a significant number of people are affected by this disease.

In 2003, the American Society of Health-System Pharmacists (ASHP) produced a document with recommendations for the main fields of pharmacist practice within the health care team, emphasizing the pharmacist's role in the care of patients with HIV infection.

Among the recommendations are: 1. Systematic evaluation of interactions, adherence and adverse effects; 2. Actions related to the monitoring process of pharmacotherapy, with the detection, prevention and resolution of other problems related to drug indication, effectiveness and safety; 3. Recognition and prevention of opportunistic infections and other potential clinical complications; 4. Education and prevention in public health, and 5. Forwarding of information and recommendations on the correct use of antiretroviral drugs, emphasizing the process of taking these drugs.

These recommendations constitute one of the areas of pharmaceutical professional practice: Pharmaceutical Care. Pharmacotherapeutic follow-up, one of the macrocomponents of Pharmaceutical Care, is carried out by the pharmacist as a process of systematic work and documented in order to optimize the therapeutic results of patients who are already undergoing medical care.

The aim of this study was to analyze the influence of pharmacotherapeutic follow-up on quality of life of HIV positive patients who are starting antiretroviral therapy, and are treated by the Pharmaceutical Care program at a specialized service in northeast Brazil.

\section{MATERIAL AND METHODS}

This is prospective controlled intervention study, in which each patient served as his own control, was developed using Pharmacotherapeutic Follow-up (PTF) of patients with STD/HIV treated at an outpatient pharmacy at a specialized medical center in Fortaleza, Ceará, during the period from November 2008 to August 2010.

The PTF, with a duration of nine months, was based on monthly meetings; there was a total of nine meetings with each patient, which were carried out in line with the Dáder method (Machuca, Fernández-Limos, Faus, 2003), and involved the following steps: 1 . invitation to receive the service; 2 . initial interview; 3 . Situational diagnosis; 4. study phase; 5 . global assessment; 6 . pharmaceutical intervention and 7. evaluation of results.

The patients were invited to participate in the PTF when they attended the pharmacy to start antiretroviral therapy, which was medically indicated. The study included patients who: had never been treated with antiretroviral drugs; began therapy during the study period; were aged over 18 years; had not participated in any pharmaceutical intervention study; and agreed to participate. Exclusion criteria were: patients who were not in a condition to reply to questions during interviews and pregnant women (who were referred to a different unit for specialized health).

The study was approved by the Ethics Committee in Research of the Federal University of Ceará - UFC (protocol number: 191/08). When the invitation was accepted, an individual interview was carried out during which explanations of the study were provided and a consent form 
signed. The interviews were conducted by the pharmacist of the health care unit with the help of an academic from the Pharmacy course at UFC. The interviewers received prior training by the Centre of Studies in Pharmaceutical Care (CEATENF-UFC).

The collection of data on sociodemographic (gender, age, marital status, education, individual income) and clinical variables (time of diagnosis and presence of signs/ symptoms at the start of therapy) was carried out using the questionnaire that had been prepared by CEATENF after meetings and focus groups. The Drug-Related Problems (DRPs) and pharmaceutical interventions were recorded and classified according to the Second Consensus of Granada (Santos et al., 2004; Sabater et al., 2005). More than one problem related to the antiretroviral drugs and interventions could be identified for a single patient.

The assessment of quality of life was divided into two phases: at the beginning (1st meeting) and at the end of PTF (9th meeting), using the instrument of Ware and Sherbourne (1992) according to the translation and validation to Brazilian-portuguese language by Ciconelli et al. (1999).

The instrument includes eight domains (physical functioning, role limitation due to physical health, bodily pain, general health perceptions, vitality, social functioning, role limitations due to emotional problems and mental health) and, for each area, a score was obtained by applying a scale measure with values from 0 to 100 , where zero corresponds to the worst result and one hundred, to the best result (Siqueira, 2005).

Data regarding the clinical and socioeconomic profiles, DRP and pharmaceutical intervention were entered into an Excel 2007 database, and analyzed descriptively, represented by tables and/or graphs. For the results regarding quality of life, a comparison between the initial and final profiles was carried out using the paired Student's t test, and the Kolmogorov-Smirnov test was used to verify the normality of the scores. The Wilcoxon test was used for samples with less than 30 individuals that did not pass the normality test. The program Sigma Plot, version 10.0, was used for the statistical analysis of quality of life, with a significance level of $5 \%$.

\section{RESULTS}

A total of 47 of the HIV + patients treated at the Unit during the study period fulfilled the requirements to participate in the project, but one patient died before the end of treatment and another abandoned the treatment, only returning after the end of the period for the PTF. Excluding these losses, the study worked with a sample of 45 patients.
The clinical and socioeconomic profile of these patients is presented in Table I. Most were male (62.2\%) with a mean age of 37.04 years $(\mathrm{SD}=11.47)$, a "single" marital status and a schooling level that was "incomplete primary" or "complete secondary". As for individual income, 42.2\% reported having an income between 1 to 2 minimum wages, which at the time of study ranged from $\mathrm{R} \$ 415.00$ to $\mathrm{R} \$ 510.00$. Regarding the signs and symptoms, 16 patients $(35.6 \%)$ reported, at the time of first interview, that they were asymptomatic, and 29 (64.4\%) reported already showing signs/symptoms of HIV infection. Regarding the time of diagnosis, more than half of patients $(55.6 \%)$ had received a diagnosis of HIV infection within the previous 12 months.

The study identified 643 problems related to antiretrovirals. The main problems were "security", mainly referring to the occurrence of adverse reactions $(58 \%$, $\mathrm{n}=373$ ) and the "necessity" for drugs, particularly related to the non-compliance to treatment/adherence problems $(27.4 \%, \mathrm{n}=176)$. Issues that were classified as "effectiveness", related to the dose of antiretroviral drugs (in this case, underdosing) were also identified $(12.9 \%, \mathrm{n}=83)$.

There were 590 pharmaceutical interventions during the follow-up. Of these, 469 could be classified according to Sabater, and were distributed in the following categories: "intervention regarding dosage" $(19.6 \%, \mathrm{n}=92)$, "change in pharmacological strategy" $(13.7 \%, \mathrm{n}=64)$ and "intervention in the education" of patients $(66.7 \%$, $\mathrm{n}=313$ ). Another 121 interventions were carried out, but these did not fit into the Sabater categories and were related to referrals to other professionals and support over biopsychosocial aspects.

When analyzing the data for question $\mathrm{N}^{\circ} 2$, which deals with the comparative evaluation between the current health status and that of one year ago, the most frequent response among respondents before the PFT was: "About the same as one year ago" (28.9\%).

After the pharmacotherapy monitoring, 24 patients responded: "Much better now than one year ago", $(53.3 \%)$. Another important fact is that before the followup, some patients $(15.6 \%, \mathrm{n}=7)$ responded to the above item as: "Much worse now than one year ago", while at the end of the study, no participant had this response to question No. 2 (Figure 1).

The analysis of data from the quality of life questionnaire domains, considering both symptomatic and asymptomatic patients, revealed that the differences between the means were statistically significant for all the domains. Furthermore, the mean values obtained at the $9^{\text {th }}$ meeting were always higher than those from the $1^{\text {st }}$ meeting (Figure 2). 
TABLE I - Distribution of socioeconomic and clinical profiles of HIV + patients under pharmacotherapeutic follow-up at a specialized treatment center ${ }^{\mathrm{a}}(\mathrm{N}=45)$

\begin{tabular}{|c|c|c|}
\hline $\begin{array}{l}\text { Variable } \\
\text {. }\end{array}$ & Frequency & Percent (\%) \\
\hline \multicolumn{3}{|l|}{ Gender } \\
\hline Male & 28 & 62.2 \\
\hline Female & 17 & 37.8 \\
\hline \multicolumn{3}{|l|}{ Age } \\
\hline 20 to 30 years & 15 & 33.3 \\
\hline $30<$ age $<40$ years & 15 & 33.3 \\
\hline $40<$ age $<50$ years & 9 & 20 \\
\hline $50<$ age $<60$ years & 4 & 8.9 \\
\hline More than 60 years old & 2 & 4.5 \\
\hline \multicolumn{3}{|l|}{ Marital Status } \\
\hline Single & 23 & 51.1 \\
\hline Married & 6 & 13.4 \\
\hline Divorced / Separated & 5 & 11.1 \\
\hline Widower & 1 & 2.2 \\
\hline Stable Relationship & 10 & 22.2 \\
\hline \multicolumn{3}{|l|}{ Education } \\
\hline Illiterate & 1 & 2.2 \\
\hline Reading and writing & 1 & 2.2 \\
\hline Incomplete primary & 15 & 33.3 \\
\hline Complete primary & 8 & 17.9 \\
\hline Incomplete high school & 2 & 4.4 \\
\hline Complete high & 14 & 31.2 \\
\hline Incomplete higher & 2 & 4.4 \\
\hline Complete higher & 2 & 4.4 \\
\hline \multicolumn{3}{|c|}{$\begin{array}{l}\text { Individual income (in minimum } \\
\text { wages - mw) }\end{array}$} \\
\hline No income & 13 & 28.9 \\
\hline$<01 \mathrm{mw}$ & 4 & 8.9 \\
\hline $01-02 \mathrm{mw}$ & 19 & 42.2 \\
\hline $02-03 \mathrm{mw}$ & 6 & 13.4 \\
\hline 03-04 mw & 1 & 2.2 \\
\hline $04-05 \mathrm{mw}$ & 0 & - \\
\hline$>05 \mathrm{mw}$ & 2 & 4.4 \\
\hline \multicolumn{3}{|l|}{ Diagnosis time } \\
\hline Up to 1 year & 25 & 55.6 \\
\hline $1<$ time $<3$ years & 10 & 22.2 \\
\hline $3<$ time $\leq 5$ years & 7 & 15.5 \\
\hline Unable to provide & 3 & 6.7 \\
\hline \multicolumn{3}{|l|}{ Signs / symptoms } \\
\hline Asymptomatic & 16 & 35.6 \\
\hline Symptomatic. & 29 & 64.4 \\
\hline
\end{tabular}

Source: Direct research- a José de Alencar Medical Specialties Center, Fortaleza, Ceará, Nov/2008- Aug/2010

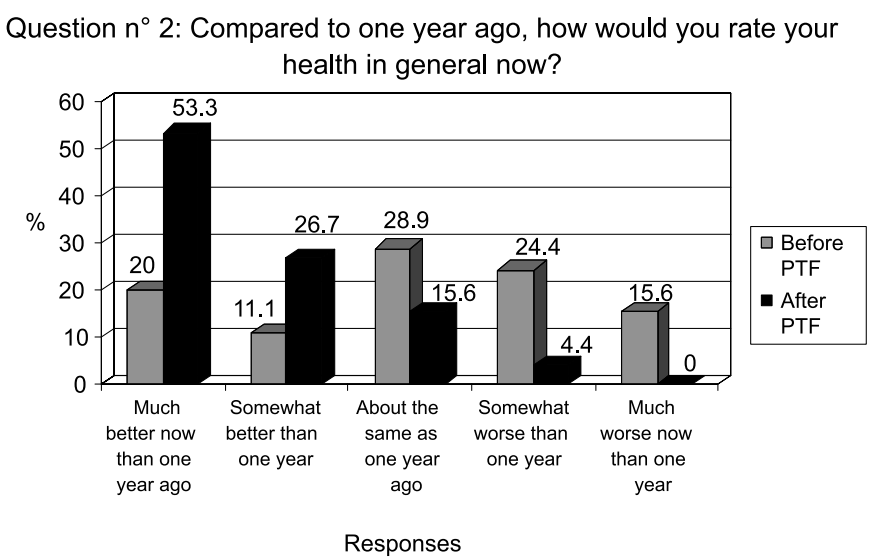

FIGURE 1 - Distribution of responses to question No. 2 of the quality of life questionnaire applied to all patients before and after the PFT $(n=45)$. Specialized treatment center ${ }^{\mathrm{a}}$, Fortaleza, Ceará, Nov/2008 - Aug/2010. a the José de Alencar Medical Specialties Center.

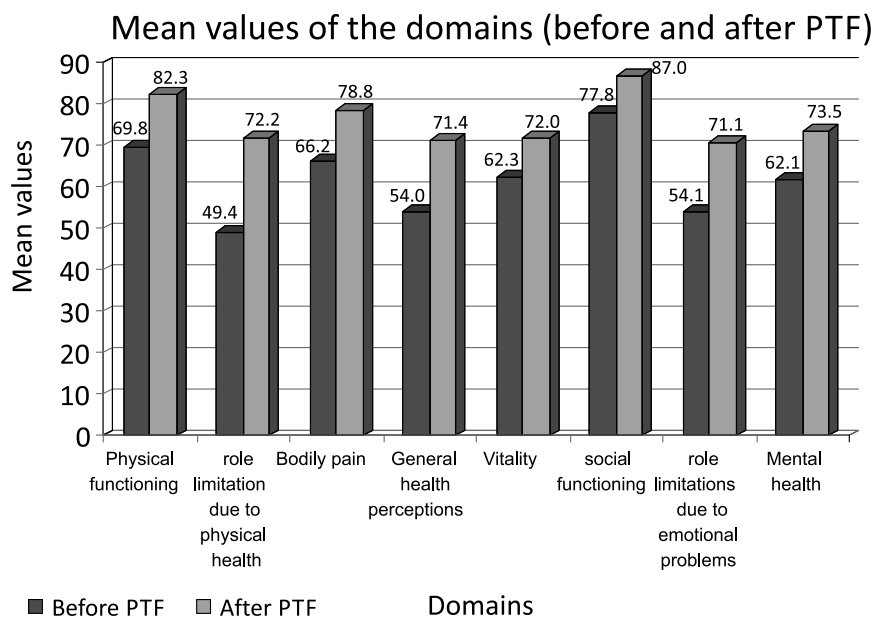

FIGURE 2 - Comparison between the mean values of the domains of the quality of life questionnaire for all patients before and after the PTF $(\mathrm{N}=45)$, Specialized treatment center ${ }^{\mathrm{a}}$, Fortaleza, Ceará, Nov/2008 - Aug/2010. The paired Student $t$ test was carried out for all domains. ${ }^{*} \mathrm{P}<0.05$. a the José de Alencar Medical Specialties Center.

The data was also analyzed by separating the symptomatic patients from the asymptomatic patients. For the asymptomatic patients, the means found for the 9 th follow-up visit were always higher than or equal to the values obtained at the 1st meeting; however, only the domain "General Health Perceptions" showed a statistically significant difference between the values obtained before and at the end of the PTF $(\mathrm{p}=0.022)$.

For the data referring only to symptomatic patients, the mean values were also all higher at the end of the PFT than during the 1 st moment (Table II) and six domains of 
TABLE II - Distribution of means, medians and standard deviations (SD) obtained for the domains of the quality of life questionnaire applied at the 1 st and $9^{\text {th }}$ PTF meeting for symptomatic HIV + patients $(n=29)$. Specialized treatment center ${ }^{\mathrm{c}}$, Fortaleza, Ceará

\begin{tabular}{lcccccccc}
\hline \multirow{2}{*}{ Domains } & \multicolumn{7}{c}{ Symptomatic patients } & \\
\cline { 2 - 7 } & \multicolumn{3}{c}{ * $\mathrm{p}$ value } \\
\cline { 2 - 7 } & Mean & Median & SD & Mean & Median & SD & \\
\hline Physical Functioning & 65.172 & 75 & 31.124 & 81.897 & 95 & 23.957 & $0.005^{\text {a }}$ \\
Role Limitation due to Physical Health & 34.483 & 0 & 45.520 & 64.655 & 100 & 45.570 & $0.009^{\text {b }}$ \\
Bodily Pain & 64.483 & 74 & 34.494 & 76.379 & 100 & 34.808 & $0.076^{\text {b }}$ \\
General Health Perceptions & 49.979 & 54 & 29.504 & 67.724 & 77 & 29.446 & $0.0066^{\text {a }}$ \\
Vitality & 58.966 & 60 & 25.508 & 68.966 & 70 & 18.916 & $0.033^{\text {a }}$ \\
Social Functioning & 73.276 & 87.5 & 32.686 & 82.759 & 100 & 24.643 & $0.167^{\text {b }}$ \\
Role Limitation due to Emotional Problems & 37.928 & 0 & 47.745 & 64.362 & 100 & 46.232 & $0.005^{\text {b }}$ \\
Mental Health & 57.793 & 60 & 25.603 & 71.103 & 72 & 22.574 & $0.011^{\text {a }}$ \\
\hline
\end{tabular}

Source: Direct Research Specialized treatment center ${ }^{\mathrm{c}}$, Fortaleza, Ceará, Nov/2008 - Aug/2010. * Level of significance $\mathrm{p}<0.05$.

${ }^{a}$ The paired Student $t$ test was carried out. ${ }^{b}$ The Wilcoxon test was carried out. ${ }^{c}$ the José de Alencar Medical Specialties Center

the questionnaire had a statistically significant difference between the initial and final mean or median: "Physical Functioning" ( $\mathrm{p}=0.005)$; "Role Limitations due to Physical Health" ( $p=0.009)$; "General Health Perceptions" $(\mathrm{p}=0.006)$; "Vitality" $(\mathrm{p}=0.033)$; "Role limitation due to emotional problems" ( $\mathrm{p}=0.005)$; and "Mental Health" $(\mathrm{p}=0.011)$.

Regarding the time of diagnosis, separate analyses were carried out, separating the patients into three groups. The first group included patients who claimed to have up to one year of diagnosis of HIV infection. Regarding the domains of the applied instrument, at the $9^{\text {th }}$ follow-up visit, this group presented means that were higher than at the beginning of monitoring (Table III), with statistically significant differences between the initial and final means and medians for the domains: "Physical Functioning" $(p=0.002)$; "General Health Perceptions" $(p<0.001)$;
"Vitality" ( $p=0.049)$;"Role Limitations due to Emotional Problems" $(p=0.016)$; and "Mental Health" $(p=0.026)$. The domain "Role limitations due to Physical Health" had a borderline p-value.

The second and third groups (that respectively included, patients with a diagnosis of more than one year but less than three years, and patients with a diagnosis of more than three years) had higher mean values at the end of the PFT, when compared with baseline values. However, in both groups, there were no significant differences between the initial and final means and medians in any of the domains of the quality of life questionnaire.

\section{DISCUSSION}

In recent years, the profile of people infected by HIV has changed (Nunes et al., 2008, Rodrigues et al., 2010).

TABLE III - Distribution of means, medians and standard deviations (SD) obtained for the domains of the quality of life questionnaires used in the 1st and 9th PTF for patients with one year of diagnosis $(n=25)$ Specialized Treatment Center, Fortaleza, Ceará

\begin{tabular}{|c|c|c|c|c|c|c|c|}
\hline \multirow{3}{*}{ Domains } & \multicolumn{6}{|c|}{ Up to 1 year of diagnosis } & \multirow{3}{*}{ * p value } \\
\hline & \multicolumn{3}{|c|}{ Before PTF } & \multicolumn{3}{|c|}{ After PTF } & \\
\hline & Mean & Median & SD & Mean & Median & SD & \\
\hline Physical Functioning & 73.8 & 80 & 25.831 & 91 & 100 & 14.361 & $0.002^{\mathrm{a}}$ \\
\hline Role Limitation due to Physical Health & 56 & 75 & 44.651 & 78 & 100 & 39.078 & $0.051^{\mathrm{b}}$ \\
\hline Bodily Pain & 70.72 & 72 & 27.923 & 85.36 & 100 & 27.236 & $0.057^{\mathrm{b}}$ \\
\hline General Health Perceptions & 58.6 & 72 & 28.362 & 80.92 & 87 & 19.278 & $<0.001^{\text {b }}$ \\
\hline Vitality & 68 & 65 & 21.311 & 76.4 & 85 & 20.079 & $0.049^{\mathrm{a}}$ \\
\hline Social Functioning & 80 & 100 & 28.868 & 89 & 100 & 22.044 & $0.216^{\mathrm{b}}$ \\
\hline Role Limitation due to Emotional Problems & 59.99 & 100 & 48.113 & 79.996 & 100 & 38.493 & $0.016^{\mathrm{b}}$ \\
\hline Mental Health & $69.12 /$ & 80 & 21.742 & 80.08 & 84 & 20.037 & $0.026^{\mathrm{a}}$ \\
\hline
\end{tabular}

Source: Source: Direct Research Specialized Treatment Center ${ }^{\mathrm{c}}$, Fortaleza, Ceará, Nov/2008 - Aug/2010. * Level of significance $\mathrm{p}<0.05 .{ }^{a}$ The paired Student $\mathrm{t}$ test was carried out. ${ }^{\mathrm{b}}$ The Wilcoxon test was carried out. ${ }^{\mathrm{c}}$ the José de Alencar Medical Specialties Center 
The profile of the participants of this study presented clinical and socioeconomic characteristics similar to those observed in other studies (Seidl et al., 2007; Saldanha, Andrade, Beck, 2009). The majority of patients interviewed were male, and the male-to-female ratio was $1.6: 1$, which is in line with a recent survey by the Ministry of Health, which revealed that, in Brazil, this ratio has been decreasing over the years and has stabilized at 1.5:1 since 2002 (Brasil, 2009). Regarding their age, also according to the records of the Ministry of Health, the majority of AIDS cases reported from 1980 to 2009 was concentrated in the age group 25-49 years. The patients enrolled in this study had a mean age of 37 years.

The majority of patients had a low level of schooling and income, which shows that there is a need to adopt measures and simple language throughout the development of the Pharmaceutical Care program for these patients. Regarding marital status, the study had a higher percentage of singles.

The profile of the patients in this study partially agrees with the profile of patients in the study by Seild et al. (2007), which involved $110 \mathrm{HIV}+$ patients. In the study by Seild, the number of singles was equal to those who live with a spouse or partner, $36.7 \%$ for each one.

The significant number of problems related to antiretroviral drugs and pharmaceutical interventions during the study reinforces the importance of PTF for the detection, resolution and prevention of problems related to therapy and the role of the pharmacist in the planning of care and treatment for each patient as part of a multidisciplinary team. In this study, problems of adherence to ART and adverse reactions were the most common problems related to specific pharmacotherapy. These issues hamper the clinical management of patients and the achievement of positive outcomes and have been observed in several other studies (Walsh et al., 2001; Bartlett, 2002; Padua et al., 2007; Guimarães et al., 2008). The pharmaceutical interventions were focused on the category "Patient Education", in line with the profile of the patients, and consisted of educational measures that stress the importance of drug therapy and adherence to it.

The questionnaire translated and validated by Ciconelli et al. (1999) to evaluate the quality of life of patients in the study was chosen because this type of generic instrument can accurately assess all significant aspects related to health and show the impact of a disease on a particular individual (Ciconelli et al., 1999; Fayers, Machin, 2000).

Question No. 2 of the questionnaire assessed current health status and baseline status (one year previously), and the vast majority of responses had higher values at the end of the PTF when compared to those obtained at the first visit. This shows that, at the end of the study, most patients considered their health to be better than before starting the follow-up.

The final means of the eight domains of the questionnaire were always higher than the initial means. At the first PTF meeting, the domains "Social Functioning", "Physical Functioning" and "Bodily Pain" had the highest means. At the end of PFT, these domains had the best results when compared to the other areas.

The study carried out by Romeo et al. (2009) found that pharmaceutical interventions during the PTF of $\mathrm{HIV}_{+}$ pregnant women were effective and helped reduce symptoms due to inadequate pharmacotherapy and contributed to the quality of life of patients.

When a distinction was made between asymptomatic and symptomatic patients, the latter had better results at the end of PTF, with a statistically significant difference for six domains, whereas among asymptomatic patients, only the domain "General Health Perceptions" was significant. This can be attributed to the fact that since they did not have any symptoms at the start of ART and during follow-up, and because the indication at the initiation of therapy was mainly determined by the results of a CD4+ cells count, the changes in quality of life were "minimal", since the treatment significantly reduces the progression of infection.

In contrast, when analyzing the patients who were symptomatic when they started ART and pharmacotherapeutic follow-up, it is easy to detect the improvement in the quality of life from the minimization and / or termination of the signs and symptoms after a few months of treatment and monitoring. It is worth emphasizing that the group of asymptomatic patients was smaller than the symptomatic group, which could explain a lack of statistically significant changes in the asymptomatic group.

As for the time of diagnosis, cross-sectional studies (Reis, 2008; Santos, França Júnior, Lopes, 2007) have demonstrated that individuals with a more recent diagnosis have lower scores in relation to certain domains of the questionnaires used in assessments of quality of life.

In this study, the group of patients with less than a year of diagnosis had the lowest scores for quality of life in the first meeting, a result that is consistent with other studies; however, after PTF, the quality of life of these patients improved, with statistical differences between the initial and final means or medians and statistical validity in five domains. This reinforces the idea that PTF contributes to improving the quality of life.

It is believed that individuals with a longer time of knowledge of the infection are more adapted to the 
changes resulting from HIV seropositivity (Reis, 2008), and present lower changes in the perception of quality of life throughout follow-up.

The results obtained in this study point towards a positive influence of pharmacotherapeutic follow-up on the quality of life of patients with HIV. It must be noted that the study population consisted of patients starting antiretroviral therapy, and thus represents a more specific population.

Furthermore, these satisfactory and significant results of the process of care were observed with only nine months of follow-up. Some authors report that a minimum of 12 months of PTF (Mazroui et al., 2009; Clifford et al, 2005), are needed to achieve beneficial results on the quality of life. Also, it is important to note that since the study was carried out at a specialized care center, which fits into the secondary level of health care, this suggests that pharmaceutical care programs can be more successful at this level of attention. One of the possible factors for this success is the facility of multidisciplinary access, integration and interaction in the planning of care and present and active participation of the pharmacist in specialized care.

\section{CONCLUSION}

Pharmacotherapeutic follow-up is developed through the detection, resolution and prevention of drugrelated problems and by carrying out pharmaceutical interventions. The results of this study suggest that PTF may be able to contribute to improving the quality of life of HIV patients, undergoing early antiretroviral therapy, especially for patients who were symptomatic and/or with up to one year of diagnosis; these represent important target groups for the practice of pharmaceutical care at a secondary health care level. However, more researches are needed to reinforce the results obtained, including studies using control groups.

\section{REFERENCES}

ABERG, J.A.; KAPLAN, J.E.; LIBMAN, H.; EMMANUEL, P.; ANDERSON, J.R.; STONE, V.E.; OLESKE, J.M.; CURRIER, J.S.; GALLANT, J.E. Primary care guidelines for the management of persons infected with human immunodeficiency virus: 2009 update by the HIV Medicine Association of the Infectious Diseases Society of America. Clin. Inf. Dis., v.49, n.5, p.651-681, 2009.
AL MAZROUI, N.R.; KAMAL, M.M.; GHABASH, N.M.; YACOUT, T.A.; KOLE, P.L.; MCELNAY, J.C. Influence of pharmaceutical care on health outcomes in patients with Type 2 diabetes mellitus. Braz. J. Clin. Pharm., v.67, n.5, p.547-557, 2009.

AMERICAN SOCIETY OF HOSPITAL PHARMACY. ASHP statement on the pharmacist's role in the care of patients with HIV infection. Am. J. Health-Syst. Pharm., v.60, n.19, p.1998-2003, 2003.

BARTLETT, J.A. Addressing the challenges of adherence. $J$. Acquir. Immune Defic. Syndr., v.29, n.1, p.2-10, 2002.

BRASIL. Ministério da Saúde. Programa Nacional de DST e AIDS. Recomendações para terapia anti-retroviral em adultos infectados pelo HIV. Brasília: Ministério da Saúde, Secretaria de Vigilância em Saúde, 2008. 244 p.

BRASIL. Ministério da Saúde. Boletim Epidemiológico - AIDS e DST. Ano VI - n ${ }^{\mathrm{o}} 1-27^{\mathrm{a}}$ a $52^{\mathrm{a}}$ - semanas epidemiológicas - julho a dezembro de 2008; $01^{\mathrm{a}}$ a $26^{\mathrm{a}}$ - semanas epidemiológicas - janeiro a junho de 2009. Ministério da Saúde - Secretaria de Vigilância em Saúde Departamento de DST, AIDS e Hepatites Virais. Available at: <www.aids.gov.br>. Accessed on: 10 nov. 2009

CANINI, S.E.M.; REIS, R.B. DOS; PEREIRA, L.A.; GIR, E.; PELÁ, N.T.R. Qualidade de vida de indivíduos com HIV/AIDS: uma revisão de literatura. Rev. Latino-Am. Enfermagem, v.12, n.6, p.940-945, 2004. Available at: <http://www.scielo.br/pdf/rlae/v12n6/v12n6a14.pdf> Accessed on: 11 oct. 2009

CHESNEY, M.A.; MORIN, M.; SHERR, L. Adherence to HIV combination therapy. Soc. Sci. Med., v.50, n.11, p.1599$1605,2000$.

CICONELLI, R.M.; FERRAZ, M.B.; SANTOS, W.S.; MEINÃO, I.M.; QUARESMA, M.R. Tradução para a língua portuguesa e validação do questionário genérico de avaliação de qualidade de vida SF-36 (Brasil SF-36). Rev. Bras. Reumatol., v.39, n.3, p.143-150, 1999.

CLIFFORD, R.M.; DAVIS, W.A.; BATTY, K.T.; DAVIS, T.M.E. Effect of a pharmaceutical care program on vascular risk factors in type 2 diabetes. Diabetes Care, v.28, n.4, p.771-776, 2005. 
FAYERS, P.; MACHIN, D. Quality of life: the assessment, analysis and interpretation of patient-reported outcomes. Chichester: Wiley, 2000. 404 p.

GUIMARÃES, M.D.C.R; ROCHA, G.M.; CAMPOS, L.N.; FREITAS, F.M.T.; GUALBERTO, F.A.S.; TEIXEIRA, R.D.R.; CASTILHO, F.M. Difficulties reported by HIVinfected patients using antiretroviral therapy in Brazil. Clinics, v.63, n.2, p.165-172, 2008.

MACHUCA, M.; FERNÁNDEZ-LLIMÓS, F.; FAUS, M.J. Método Dáder. guía de seguimiento farmacoterapêutico. GIAF-UGR. Granada: La Gráfica S.C.And. Granada, 2003. $47 \mathrm{p}$.

NUNES, A.A.; SILVA-VERGARA, M.L.; MELO, I.M.; SILVA, A.L.A.; REZENDE, L.S.A.; GUIMARÃES, P.B. Perfil clínico-epidemiológico de pacientes com HIV/Aids internados em um hospital de ensino do Brasil Clinical and epidemiologic profile of hospitalized patients with HIV/ Aids. Rev. Panam. Infectol., v.10, n.3, p.26-31, 2008.

PÁDUA, C.A.M.; CÉSAR, C.C.; BONOLO, P.F.; ACURCIO, F.A.; GUIMARÃES, M.D.C. Self-reported adverse reactions among patients initiating antiretroviral therapy in Brazil. Braz. J. Infect. Dis., v.11, n.1, p.20-26, 2007.

PALELLA, F.J.P.; DELAEY, K.M.; MOORMAN, A.C.; LOVELESS, M.O.; FUHRER, J.; SATTEN, G.A.; ASCHMAN, D.J.; HOLMBERG, S.D. Declining morbility and mortality among patients with advanced human immunodeficiency virus infection. N. Engl. J. Med., v.338, n.13, p.853-860, 1998.

REIS, R K. Qualidade de vida de portadores de HIV/AIDS: influência dos fatores demográficos clínicos e psicossociais. Ribeirão Preto, 2008. 274 f. [Thesis of PhD Degree. School of Nursing of Universaity of São Paulo, Ribeirão Preto].

RODRIGUES NETO, J.F.; LIMA, L.S.; ROCHA, L.F.; LIMA, J.S.; SANTANA, K.R.; SILVEIRA, M.F. Perfil de adultos infectados pelo vírus da imunodeficiência humana (HIV) em ambulatório de referência em doenças sexualmente transmissíveis no norte de Minas Gerais. Rev. Med. Minas Gerais, v.20, n.1, p.22-29, 2010.

ROMEU, G.A.; PAIVA, L.V.; MOURAFÉ, M.M. Pharmaceutical care to pregnant women carrying human immunodeficiency virus. Braz. J. Pharm. Sci., v.45, n.3, p.593-602, 2009.
SABATER, D.; FERNANDEZ-LLIMOS, F.; PARRAS, M.; FAUS, M.J. Tipos de intervenciones farmacéuticas en seguimiento farmacoterapéutico. Seguim. Farmacoter., v.3, n.2, p.90-97, 2005.

SALDANHA, J.S.; ANDRADE, C.S.; BECK, S.T. Grau de adesão ao tratamento com anti-retrovirais entre indivíduos HIV positivos atendidos no Hospital Universitário de Santa Maria. Saúde, v.35, n.1, p.4-9, 2009.

SANTOS, E.C.M.; FRANÇA Jr, I.; LOPES, F. Qualidade de vida de pessoas vivendo com HIV/Aids em São Paulo. Rev. Saúde Pública, v.41, n.2, p.64-71, 2007.

SANTOS, H.; IGLÉSIAS, P.; FERNÁNDEZ-LLIMÓS, F.; FAUS, M.J.; RODRIGUES, L.M. Segundo consenso de Granada sobre problemas relacionados com medicamentos - Tradução intercultural de Espanhol para Português (europeu). Acta Med. Port., v.17, n.1, p.59-66, 2004.

SEIDL, E.M.F; MELCHÍADES, A.; FARIAS, V.; BRITO, A. Pessoas vivendo com HIV/AIDS: variáveis associadas à adesão ao tratamento anti-retroviral. Cad. Saúde Pública, v.23, n.10, p.2305-2316, 2007.

SIQUEIRA, S.M.F. O questionário genérico SF-36 como instrumento de mensuração da qualidade de vida relacionada à saúde de pacientes hipertensos. Ribeirão Preto, 2005. 112 p. [Thesis of PhD degree. School of Nursing of Univerisity of São Paulo].

WALSH, J.C.; HORNE, R.; DALTON, M.; BURGESS, A.P.; GAZZARD, B.G. Reasons for non-adherence to antiretroviral therapy: patient's perspectives provide evidence of multiple causes. AIDS Care, v.13, n.6, p.709$720,2001$.

WARE, J.E.; SHERBOURNE, C.D. The MOS 36-Item ShortForm Health Survey (SF-36): I. Conceptual framework and item selection. Medical Care, v.30, n.6, p.473-83, 1992.

Received for publication on $19^{\text {th }}$ November 2011 Accepted for publication on $28^{\text {th }}$ August 2012 